\title{
Prediksi Kebangkrutan pada Bank BUMN dengan Menggunakan Metode Altman Z-Score Modifikasi Periode 2019
}

\author{
Bankruptcy prediction state-owned banks based on the Altman Z-Score modification \\ method in the 2019 period
}

\author{
Nita Kurniasih \\ Program Studi D3 Keuangan dan Perbankan, Politeknik Negeri Bandung \\ Email: nita.kurniasih.kepn17@polban.ac.id
}

\section{Muhammad Umar Mai}

Jurusan Akuntansi, Politeknik Negeri Bandung

Email: umar.mai@polban.ac.id

\section{Rani Putri Kusuma Dewi}

Program Studi Magister Ekonomi Islam, UIN Sunan Gunung Djati Bandung

Email: putrikusumadewirani@gmail.com

\begin{abstract}
The purpose of this research is to predict the possibility of bankruptcy occur in company. The sample in this research used four state-owned banks, namely Bank BRI, Bank BNI, Bank Mandiri dan Bank BTN. The research method used is descriptive analysis techniques and tool used in predicting bankcruptcy is by using model Altman Z-Score modification. The research period used is the period 2019 with secondary data obtained from the annual financial report of state-owned bank. The result of this research conclude that all of four state-owned banks are in the grey area for the 2019 period because the value of the Z-Score obtained is between 1,10 and 2,90.
\end{abstract}

Keywords: bankruptcy prediction, altman z-score, state-owned banks

\section{Pendahuluan}

Perbankan memiliki andil yang penting dalam memajukan perekonomian suatu negara. Bank sebagai lembaga keuangan yang memiliki wewenang untuk menghimpun dana masyarakat dan menyalurkannya kembali ke masyarakat. Sehingga dapat dikatakan, bahwa perbankan merupakan suatu perusahaan yang dalam menjalankan kegiatan usahanya berhubungan langsung dengan masyarakat. Untuk mempertahankan kepercayaan masyarakat sebagai lembaga keuangan yang menghimpun dana masyarakat, perusahaan perbankan menjaga kondisi finansial perusahaan terhindar dari kesulitan keuangan atau bahkan sampai mengalami kebangkrutan.

Ditinjau dari segi kepemilikan, salah satu jenis bank yaitu Bank pemerintah atau Bank BUMN. Bank BUMN adalah suatu bank yang sebagian besar modalnya dimiliki oleh pemerintah. Dibandingkan dengan bank-bank swasta, bank BUMN memiliki nominal permodalan yang relatif besar. Dapat dikatakan bahwa Bank BUMN memiliki sumbangsih besar dalam menggerakkan industri perbankan di Indonesia. Bank BUMN sebagai market leader dengan pangsa pasar yang besar dan luas dapat mempengaruhi kinerja perbankan secara nasional. Jika bank BUMN memiliki kinerja bank yang baik, maka dapat berdampak positif pada kinerja perbankan Indonesia secara 
keseluruhan, dan sebaliknya.

Lembaga Penjamin Simpanan (LPS) menyatakan telah menggelontorkan dana sebesar Rp1,4 triliun untuk melikuidasi atau menutup 97 bank sejak 2005 hingga Juli 2019 (CNN Indonesia, 28 Juli 2019). Berdasarkan fenomena kebangkrutan yang terjadi, maka penting bagi bank tak terkecuali bagi Bank BUMN untuk mengenali gejala-gejala keuangan yang mengarah pada kebangkrutan.

Salah satu tindakan yang bisa dilakukan perusahaan perbankan untuk menghindari terjadinya bank dilikuidasi, yaitu dengan melakukan prediksi kebangkrutan sedini mungkin sehingga manajemen dapat mengantisipasinya dengan merencanakan tindakan-tindakan yang tidak saling merugikan (Nurdin, 2005). Untuk mengindikasi potensi kebangkrutan dapat menggunakan modelmodel prediksi yang telah dirumuskan oleh para ilmuwan. Salah satu model prediksi kebangkrutan yaitu model Altman Z-Score. Pemanfaatan model prediksi kebangkrutan ini dapat membantu pihak manajemen dalam upaya mengantisipasi terjadinya kebangkrutan.

Salah satu pemberitaan menyatakan bahwa pertumbuhan laba bersih empat bank pelat merah (bank BUMN) tercatat mengalami pelambatan pada 2019. Dari keempat bank BUMN tersebut tiga diantaranya mengalami pertumbuhan yang lambat dibanding tahun sebelumnya, dan satu bank mengalami penurunan laba bersih yang dratis (katadata.co.id, 24 Februari 2020).

Untuk melihat kinerja suatu perusahaan perbankan dapat bertahan,tumbuh dan berkembang atau bahkan bangkrut salah satu indikatornya yaitu dengan melihat hasil laba bersih bank tersebut. Berikut ini merupakan grafik laba bersih yang dihasilkan Bank BUMN periode 2018-2019 :

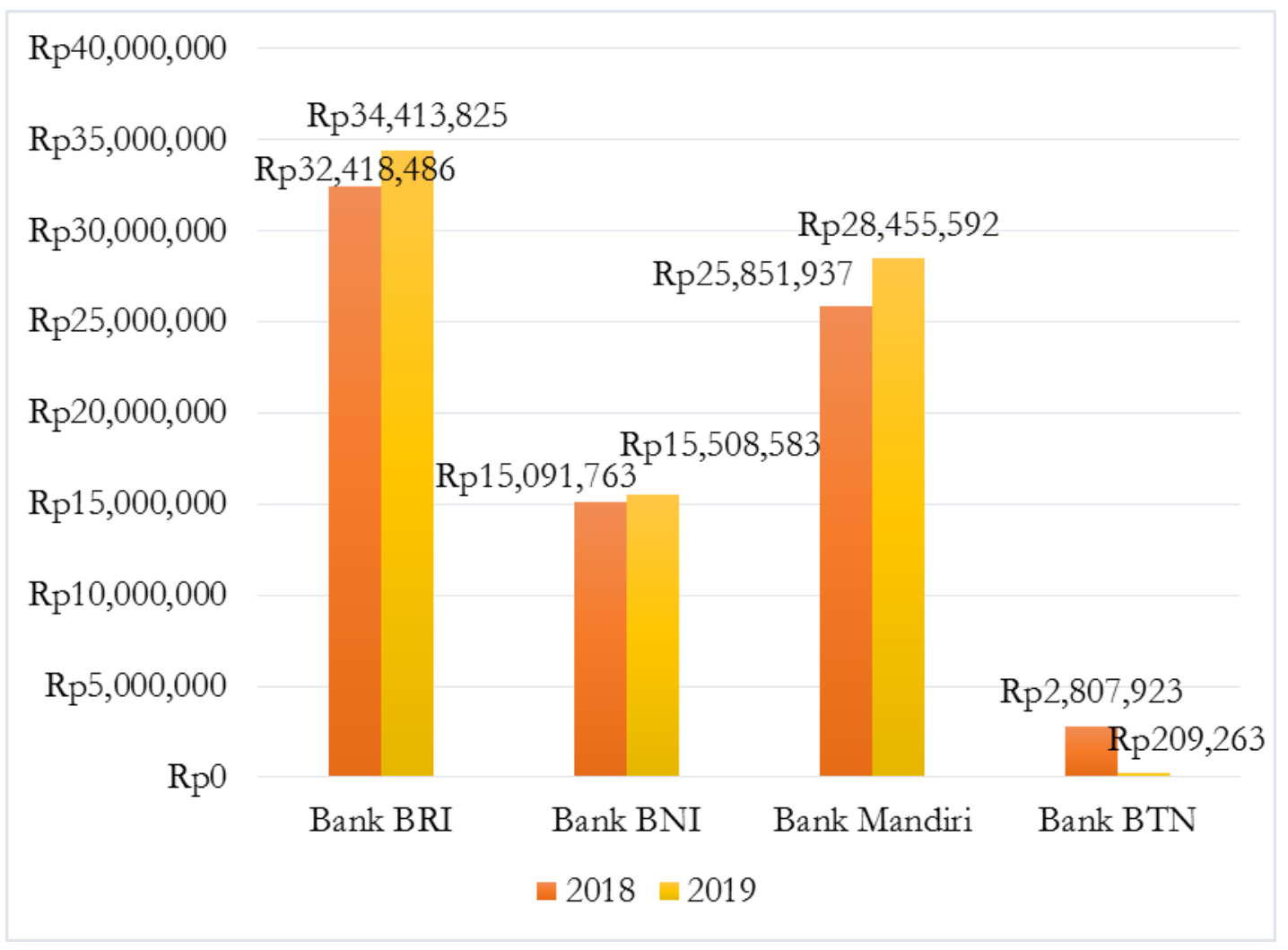

Gambar 1. Data Pertumbuhan Laba pada Bank BUMN periode 2018 - 2019 (dalam juta rupiah) Sumber : www.idx.co.id, data diolah untuk penelitian 
Pada Gambar 1 menunjukkan bahwa dari tahun 2018 ke tahun 2019 tiga dari empat Bank BUMN mengalami peningkatan laba yang cukup baik, sedangkan satu bank BUMN mengalami penurunan laba. Melihat kondisi keuangan Bank BTN pada tahun 2019 yang mengalami penurunan laba yang drastis, penulis tertarik untuk meneliti kemungkinan terjadi kebangkrutan pada Bank BTN dan juga tidak menutup kemungkinan akan terjadi kebangkrutan pada ketiga bank BUMN lainnya.

Dengan demikian, berdasarkan latar belakang diatas, maka permasalahan dalam penelitian ini adalah bagaimana prediksi kebangkrutan dari Bank BUMN untuk periode 2019 dengan menggunakan metode Altman Z-Score Modifikasi dan Bagaimana potensi kebangkrutan Bank BUMN periode 2019 jika dikelompokkan dalam kategori safezone (tidak bangkrut), greyzone (rawan bangkrut), dan distresszone (bangkrut) menggunakan model Altman Z-Score Modifikasi.

\section{Kajian Pustaka}

Kebangkrutan (bankruptcy) dapat diartikan sebagai gagalannya suatu perusahaan dalam menjalankan kegiatan usaha untuk memperoleh laba (Supardi, 2003). Sedangkan menurut UndangUndang No.4 Tahun 1998 tentang kepailitan, menyatakan bahwa kebangkrutan sebagai situasi yang dinyatakan pailit oleh keputusan pengadilan. Kebangkrutan sering juga disebut likuidasi perusahaan atau penutupan perusahaan ataupun insolvabilitas.

Kebangkrutan merupakan suatu kondisi suatu perusahaan tidak mampu melanjutkan kegiatan usaha opersionalnya disebabkam kondisi finansial yamg dimiliki mengalami kemrosotan dan terdapat kewajiban atau hutang yang nilai nominalnya lebih besar dibandingkan nilai aktiva yang dimiliki perusahaan. Sehingga perusahaan dapat dinyatakan pailit oleh putusan pengadilan yang berwenang, baik atas permohonannya sendiri, maupun permohonan seorang atau lebih krediturnya.

Prediksi kebangkrutan memiliki fungsi sebagai acuan bagi pihak-pihak berkepentingan mengenai kinerja keuangan perusahaan. Karena persoalan kebangkrutan merupakan hal yang serius, oleh karena itu manajemen perlu membangun suatu sistem yang memberikan peringatan awal munculnya indikasi perusahan akan mengalami kesulitan keuangan yang nantinya akan mengantarkan perusahaan dalam kondisi kebangkrutan. Sehingga apabila indikasi tersebut mulai muncul, manajemen dapat melakukan rencana tindakan yang akan diambil untuk memperbaiki kondisi keuangan sedini mungkin dari ancaman kebangkrutan.

Edward Altman merupakan seorang profesor di New York University. Edward melakukan penelitian terhadap perusahaan yang memiliki kinerja keuangan sehat dan perusahaan yang mengalami kinerja keuangan sulit dalam artian menghadapi kebangkrutan. Edward menggunkan teknik statistik berupa Analisis Diskiriminan Ganda yang memiliki kegunaan untuk mengklasifikasikan objek menjadi beberapa kelompok. Hasil penelitiannya dirumuskan dalam persamaan matematika yang disebut dengan rumus Altman Z-Score. Persamaan rumus Altman ZScore menggunakan variabel dari kompenen dalam laporan keuangan sebagai alat prediksi kemungkinan terjadinya kebangkrutan pada perusahaan. Pada awal pembuatan model prediksi Altman Z-Score, Altman gunakan untuk memeriksa 85 perusahaan manufaktur sebagai sampel. Kemudian model model prediksi Altman Z-Score dikembangkan untuk perusahaan manufaktur tertutup dan perusahaan jasa.

Berdasarkan Analisis Diskriman Ganda, Edward menentukan nilai koefisien untuk masingmasing rasio keuangan. Hasil penjumlahan dan perkalian dari nilai koefisien dengan rasio keuangannya menghasilnya nilai multivariasi. Oleh Edward nilai multivariasi ini dinamakan dengan Z-Score. Dalam penelitian ini model Altman yang digunakan adalah model Altman Z-Score yang telah dimodifikasi untuk perusahaan perbankan. Berikut ini merupakan persamaan rumus Altman 
Z-Score Modifikasi :

$$
Z=6,56 X_{1}+3,26 X_{2}+6,72 X_{3}+1,05 X_{4}
$$

Dimana :

$\mathrm{X}_{1}$ : Working capital to total assets

$\mathrm{X}_{2}$ : Retained earning to total assets

$\mathrm{X}_{3}$ : Earning before interest and taxes to total assets

$\mathrm{X}_{4}$ : Market value equity to total assets

$\mathrm{Z}$ : Overall index

Klasifikasi kondisi kebangkrutan berdasarkan nilai titik cutoff untuk persamaan Model Altman Z-Score Modifikasi, adalah sebagai berikut:

a. $\mathrm{Z} \leq 1,10$. Disstress zone (perusahaan terancam mengalami kebangkrutan).

b. 1,10<Z 2,90. Grey zone (perusahaan berada dalam kondisi rawan bangkrut).

c. $Z \geq 2,90$. Safe zone (kondisi keuangan perusahaan sehat dalam artian tidak ada masalah keuangan).

Dalam penelitian ini penulis menggunakan empat rasio model Altman Z-Score Modifikasi n untuk mengukur kondisi keuangan suatu perusahaan perbankan sehat atau memiliki potensi bangkrut, yaitu sebagai berikut :

1. Working Capital to Total Assets Ratio $\left(\mathrm{X}_{1}\right)$

Rasio $\mathrm{X}_{1}$ mengukur likuiditas perusahaan atau untuk melihat kemampuan perusahaan dalam memenuhi kewajiban jangka pendeknya dengan membandingkan modal kerja dengan total aktiva yang dimiliki. Dimana modal kerja merupakan total aktiva lancar dikurangi total kewajiban lancar.

2. Retained Earning to Total Assets Ratio $\left(\mathrm{X}_{2}\right)$

Rasio $\mathrm{X}_{2}$ mengukur kemampuan perusahaan dalam menghasilkan laba ditahan dari penggunaan total aktiva. Retained earning atau laba ditahan merupakan sisa laba bersih yang telah dikurangi dividen.

\section{Earning Before Interest and Taxes to Total Assets Ratio $\left(\mathrm{X}_{3}\right)$}

Rasio $\mathrm{X}_{3}$ digunakan untuk mengukur seberapa besar produktivitas penggunaan aktiva perusahaan atau seberapa besar laba yang dihasilkan dari penggunaan aktiva perusahaan, yaitu dengan membandingkan laba sebelum bunga dan pajak (EBIT) perusahaan dengan total aktiva.

\section{Market Value of Equity to Book V alue Of Liabilities Ratio $\left(\mathrm{X}_{4}\right)$}

Rasio $\mathrm{X}_{4}$ merupakan rasio aktivitas yang mengukur kemampuan perusahaan dalam memberikan jaminan kepada setiap utangnya melalui modal sendiri, yaitu dengan membandingkan nilai pasar ekuitas dengan nilai buku utang.

Berdasarkan latar belakang masalah beserta kajian pustaka dan penelitian terdahulu maka kerangka pemikiran dalam penelitian ini dapat digambarkan sebagai berikut : 


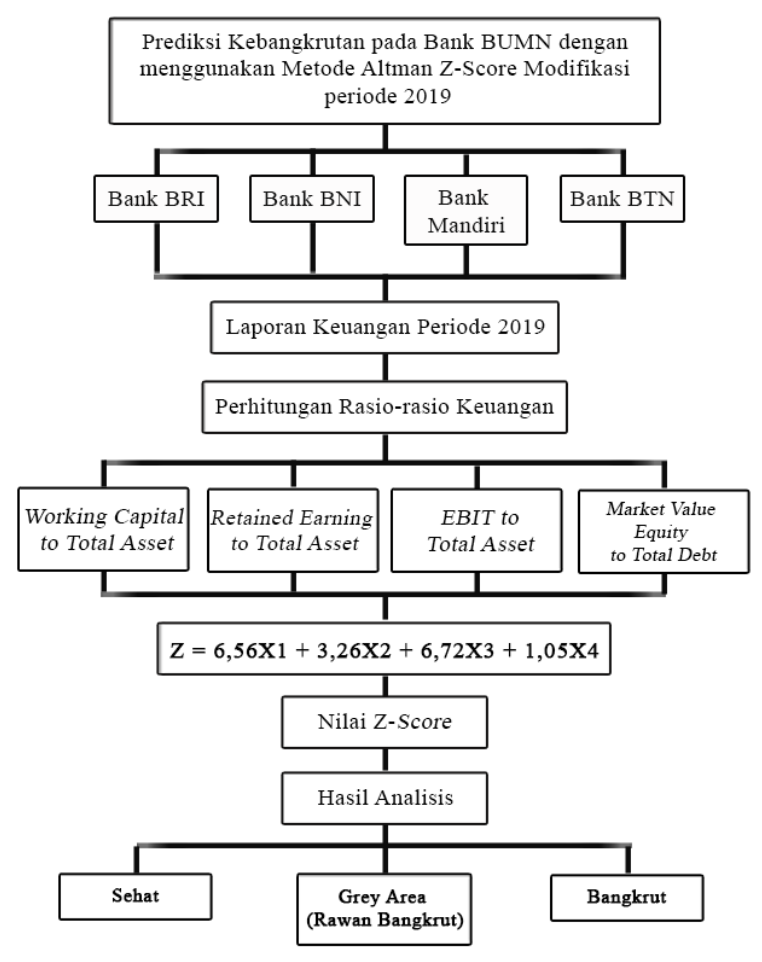

Gambar 2. Kerangka Pemikiran

\section{Metode Penelitian}

Penelitian ini menggunakan metode deskriptif kuantitatif. Pada dasarnya penelitian deskriptif kuantitatif adalah jenis penelitian yang menguraikan secara rinci dan mendalam terhadap objek penelitian untuk menguji hipotesis yang telah ditetapkan dengan menggunakan analisis data yang bersifat kuantitatif atau statistik.

Dalam penelitian ini menggunakan data sekunder. Data sekunder ini berupa laporan keuangan neraca dan laba rugi tahunan Bank BUMN periode 2019. Jenis data yang digunakan ini adalah data kuantitatif yang mengutamakan analisis data dengan metode statistik.

Data yang akan diolah dalam penelitian ini diperoleh dari situs resmi Bursa Efek Indonesia www.idx.co.id, dan situs resmi tiap-tiap Bank BUMN. Teknik yang digunakan dalam pengumpulan data penelitian adalah teknik dokumentasi.

Pada penelitian ini penulis menggunakan statistika deskriptif. Statistika deskritif yaitu suatu metode penelitian untuk mengetahui nilai variabel mandiri (variabel yang berdiri sendiri, bukan variabel independen), baik satu variabel atau lebih tanpa menghubungkan dengan variabel lain (Sugiyono, 2015). Pada penelitian ini terdapat tahap-tahapan untuk menganalisis data, diantaranya sebagai berikut :

1. Menghitung pengolahan data dengan cara menghitung keempat rasio keuangan perusahan yang terdapat pada model Altman Z-Score. Rasio keuangan tersebut adalah sebagai berikut:

a. Working Capital to Total Assets $\left(\mathrm{X}_{1}\right)$

$$
\text { Metode perhitungan }=\frac{\text { Working Capital }}{\text { Total Assets }}
$$


(Working Capital merupakan selisih dari aktiva lancar dan hutang lancar)

b. Retained Earning to Total Assets $\left(\mathrm{X}_{2}\right)$

Metode perhitungan $=\frac{\text { Retained Earning }}{\text { Total Assets }}$

(Retained Earning merupakan selisih dari laba yang didistribusikan dengan dividen)

c. Earnong Before Interest and Taxes to Total Assets $\left(\mathrm{X}_{3}\right)$

Metode perhitungan $=\frac{E B I T}{\text { Total } A \text { ssets }}$

d. Market Value of Equity to Book V alue of Total Debt $\left(\mathrm{X}_{4}\right)$

Metode perhitungan $=\frac{\text { Market Value of Equity }}{\text { Book Value of Total Debt }}$

(Market V alue Equity merupakan hasil kali dari jumlah saham beredar dengan harga pasar per lembar saham)

2. Menghitung nilai Z-Score setiap perusahaan yang menjadi objek penelitian dengan rumus sebagai berikut :

$$
Z=6,56 X_{1}+3,26 X_{2}+6,72 X_{3}+1,05 X_{4}
$$

3. Mengklasifikasi perusahaan perbankan berdasarkan nilai titik cutoff model Altman Z-Score dengan kriteria sebagai berikut :

a. Nilai $Z$ score $\leq 1,10$ berarti perusahaan diprediksi mengalami kebangkrutan.

b. Nilai $Z$ score $1,10<Z<2,90$ berarti perusahaan dianggap berada pada grey zone atau rawan bangkrut.

c. Nilai $Z$ score $\geq 2,90$ berarti perusahaan dalam keadaan sehat atau tidak terdapat masalah keuangan.

\section{Hasil dan Pembahasan}

Pada bab sebelumnya telah disebutkan pada rasio Altman Z-Score Modifikasi terdiri dari 4 (empat) rasio keuangan yang berfungsi untuk menilai potensi kebangkrutan suatu perusahaan perbankan. Keempat rasio keuangan tersebut terdiri atas Working Capital to Total Assets $\left(\mathrm{X}_{1}\right)$, Retained Earning to Total Assets ( $\left.\mathrm{X}_{2}\right)$, Earning Before Interest And Taxes to Total Assets ( $\left.\mathrm{X}_{3}\right)$, Dan Market Value Of Equity to Book. Value Of Total Debt $\left(\mathrm{X}_{4}\right)$ :

\section{Working Capital to Total Assets ( $\left.\mathrm{X}_{1}\right)$}

Working capital to toal assets merupakan rasio modal kerja terhdaap total aktiva yang digunakan untuk mengukur likuiditas dengan membandingkan antara modal kerja dengan total aktiva. Working capital atau modal kerja yang dimaksud dalam penelitian ini adalah net working capital (modal kerja bersih) yang diperoleh dari perhitungan aktiva lancar dikurangi hutang lancar. Berdasarkan hasil penelitian diperoleh hasil perhitungan rasio $\mathrm{X}_{1}$ pada Gambar 3. 


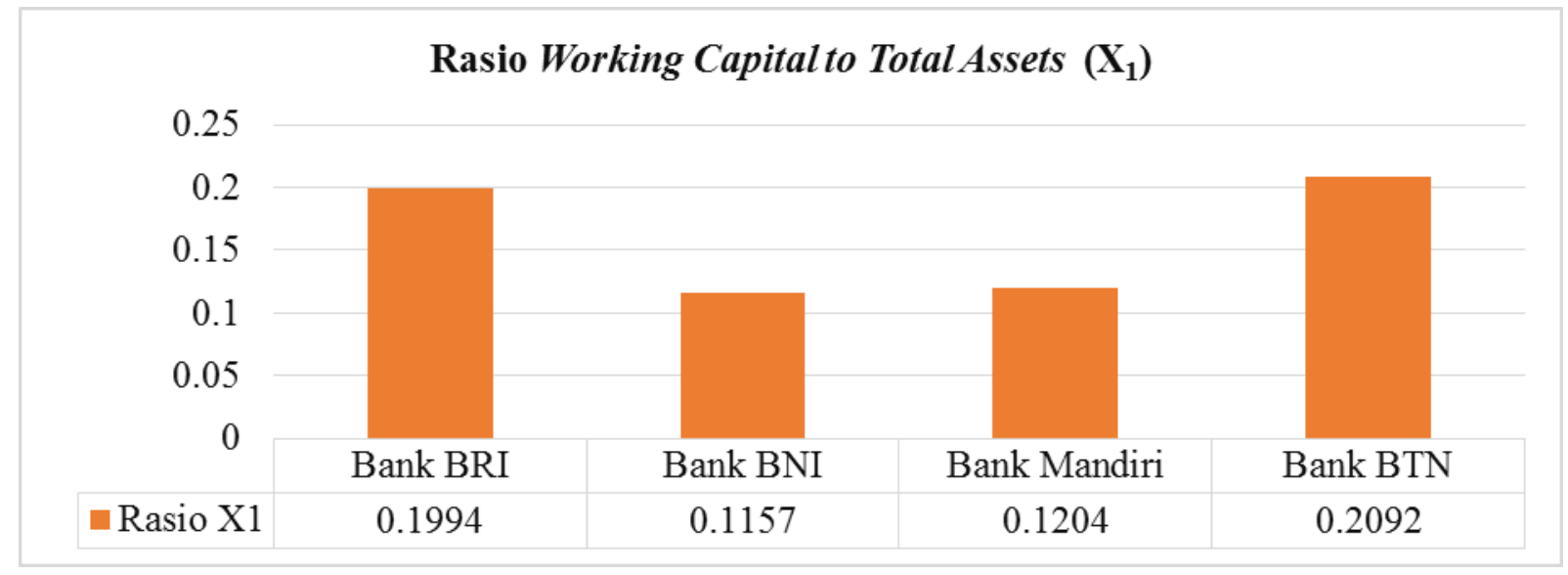

Gambar 3. Perhitungan Rasio Working Capital to Total Assets $\left(\mathrm{X}_{1}\right)$ Bank BUMN periode 2019

Berdasarkan Gambar 3 tersebut diketahui perhitungan modal kerja bersih terhadap total asset yang dimiliki oleh masing-masing Bank BUMN. Hasil perhitungan nilai rasio $\mathrm{X}_{1}$ terendah ditempatii oleh Bank BNI yaitu sebesar 0,1157 atau 11,57\% yang artinya setiap penggunaan Rp 1 aset yang dimiliki oleh Bank BRI maka modal kerja bersih yang akan diperoleh sebesar Rp 0,1157. Dan nilai rasio $X_{1}$ tertinggi diduduki oleh Bank BTN sebesar 0,2092 atau 20,92\% yang memiliki arti setiap penggunaan Rp 1 al=ktiva yang dimiliiki oleh Bank BTN maka akan memperoleh modal kerja bersih sebesar Rp 0,2092. Sedangkan Bank BRI dan Bank Mandiri mendapatkan nilai rasio $\mathrm{X}_{1}$ ) masing-masing sebesar 0,1994 atau 19,94\% dan 0,1204 atau 12,04\%.

\section{Retained Earning to Total Assets $\left(\mathrm{X}_{2}\right)$}

Retained earning to Total Assets $\left(\mathrm{X}_{2}\right)$ digunakan untuk mengukur kemampuan perusahaan dalam menghasilkan laba ditahan dari penggunaan total aktiva. Retained earning atau laba ditahan merupakan sisa laba bersih yang telah dikurangi dividen. Berdasarkan hasil penelitian diperoleh hasil perhitungan rasio $\mathrm{X}_{2}$ pada Gambar 4.

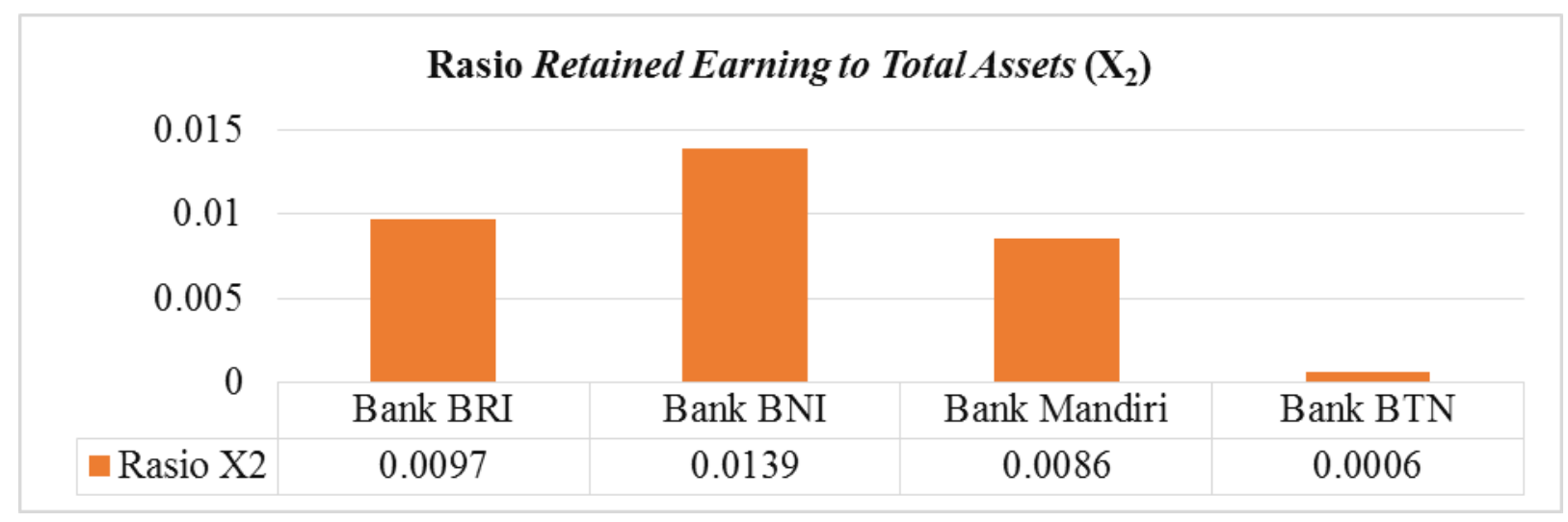

Gambar 4. Perhitungan Rasio Retained Earning to Total Assets $\left(\mathrm{X}_{2}\right)$ Bank BUMN periode 2019

Berdasarkan Gambar 4 tersebut diketahui perhitungan laba yang ditahan terhadap total aset yang dimiliki oleh masing-masing Bank BUMN.. Hasil perhitungan nilai rasio $\mathrm{X}_{2}$ terendah dimiliki oleh Bank BTN yaitu sebesar 0,0006 atay 0,06\% yang artinya setiap penggunaan Rp1 aktiva yang dimiliki oleh Bank BTN akan menghasilkan laba yang ditahan sebesar Rp0,0006. Dan nilai rasio $\mathrm{X}_{2}$ tertinggi dimiliki oleh Bank BNI sebesar 0,0139 atau 1,39\% yang memiliki arti setiap penggunaan 
Rp1 aktiva yang dimiliki oleh Bank BNI akan menghasilkan laba yang ditahan sebesar Rp0,0139. Sedangkan Bank BRI dan Bank Mandiri memiliki nilai rasio $\mathrm{X}_{2}$ masing-masing sebesar 0,0097 atau $0,97 \%$ dan 0,0086 atay $0,86 \%$

\section{Earning Before Interest and Taxes to Total Assets $\left(\mathrm{X}_{3}\right)$}

Earning Before Interest and Taxes (EBIT) to Total Assets ( $\left.\mathrm{X}_{3}\right)$ digunakan untuk menilai kemampuan perusahaan dalam memperoleh laba sebelum bunga dan pajak terhadap total aktiva yang dimiliki perusahaan. Bedasarkan hasil penelitian diperoleh hasil perhitungan rasio $\mathrm{X}_{3}$ pada Tabel 5.

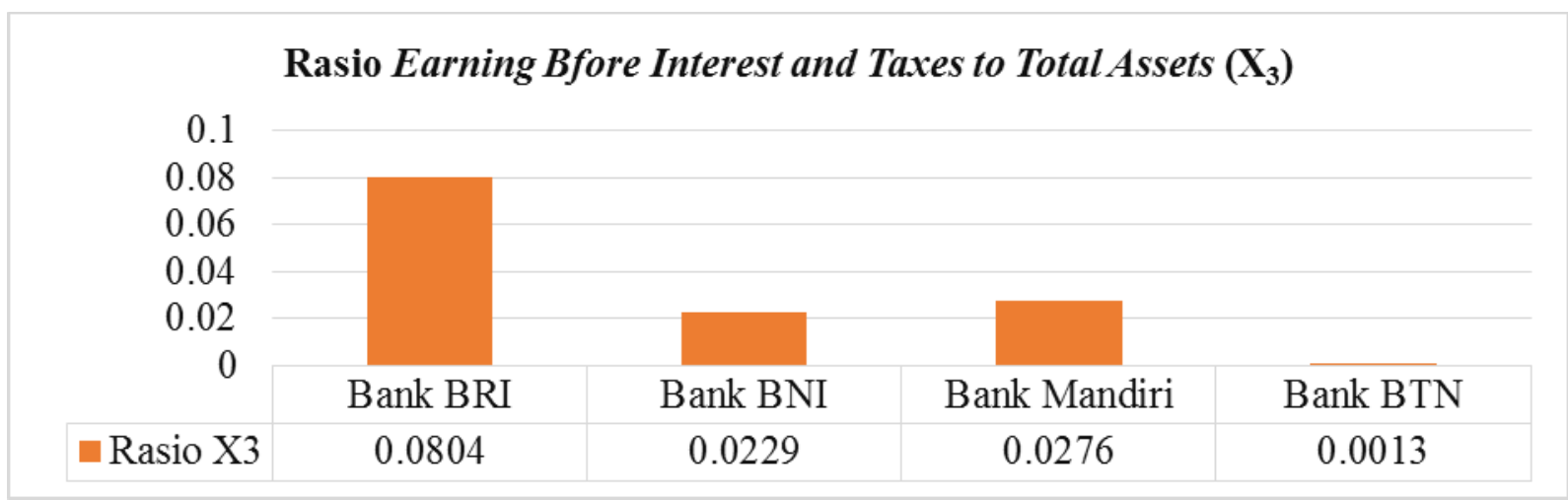

Tabel 5. Perhitungan Rasio Earning Before Interest and Taxes (EBIT) to Total Assets $\left(\mathrm{X}_{3}\right)$ Bank BUMN periode 2019

Berdasarkan Tabel 5 tersebut diketahui perhitungan pendapatan sebelum bunga dan pajak terhadap total aset. Hasil perhitungan nilai rasio $\mathrm{X}_{3}$ terendah dimiliki oleh Bank BTN yaitu sebesar 0,0013 atau 0,13\% yang artinya setiap pemakaian Rp1 aktiva yang dimiliki Bank BTN akan menghasilkan EBIT sebesar Rp0,0013. Dan nilai rasio $\mathrm{X}_{3}$ tertinggi dimiliki oleh Bank BRI sebesar 0,0804 atau 8,04\% yang berarti setiap pemakaian Rp1 aktiva yang dimiliki oleh Bank BRI akan menghasilkan EBIT sebesar Rp0,0804. Sedangkan Bank BNI dan Bank Mandiri memiliki nilai rasio $\mathrm{X}_{3}$ masing-masing sebesar 0,0229 atau $2,29 \%$ dan 0,0276 atau $2,76 \%$. 


\section{Market Value of Equity to Book V alue of Total Debt $\left(\mathrm{X}_{4}\right)$}

Market $V$ alue of Equity to Book V alue of Total Debt $\left(\mathrm{X}_{4}\right)$ merupakan rasio yang digunakan untuk menilai seberapa besar kemampuan permodalan perushaan dapat menanggung seluruh beban hutangnya. Berdasarkan hasil penelitian diperoleh hasil perhitungan rasio $\mathrm{X}_{4}$ pada Gambar 6 .

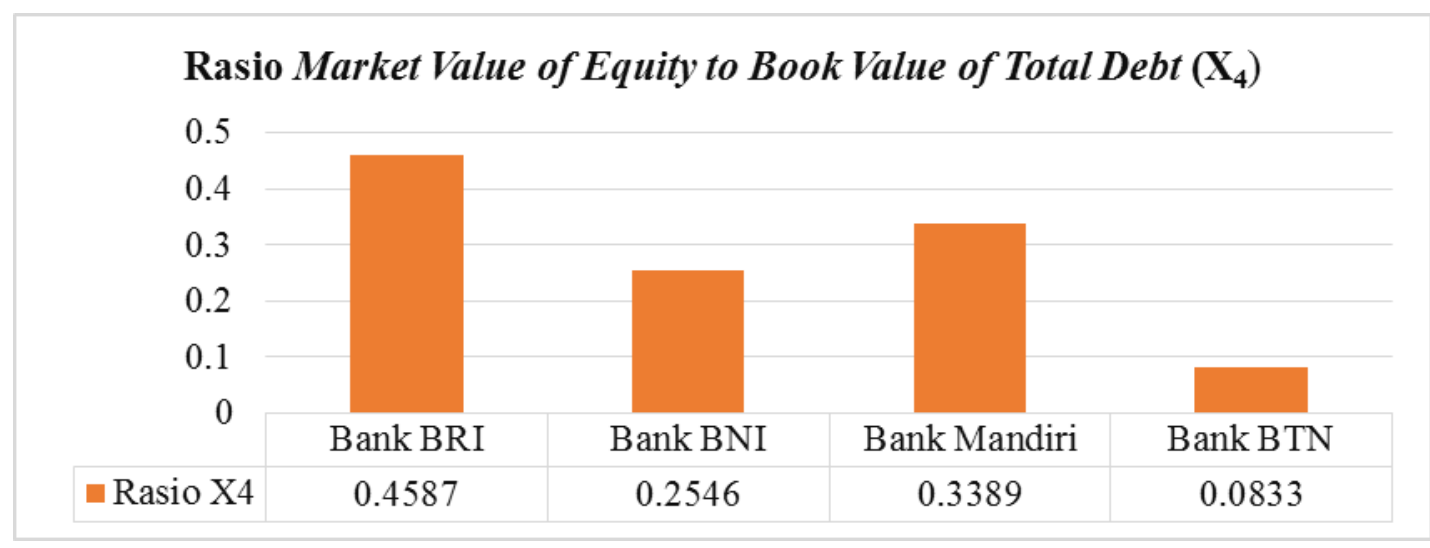

Gambar 6. Perhitungan Rasio Market V alue of Equity to Book V alue of Total Debt $\left(\mathrm{X}_{4}\right)$ Bank BUMN periode 2019

Berdasarkan Tabel 6 tersebut diketahui perhitungan nilai pasar ekuitas terhadap nilai buku hutang yang dimiliki oleh masing-masing Bank BUMN. Hasil perhitungan nilai rasio $\mathrm{X}_{4}$ terendah ditempati oleh Bank BTN yaitu sebesar 0,0833 atau 8,33\% yang artinya setiap penggunaan Rp1 utang yang dimiliki oleh Bank BTN dicakup sebesar Rp 0,0833 oleh nilai pasar ekuitas. Dan nilai rasio $\mathrm{X}_{4}$ tertinggi dimiliki oleh Bank BRI sebesar 0,4587 atau 45,87\% yang memiliki arti setiap penggunaan Rp1 utang yang dimiliki Bank BRI dicakup sebesar Rp 0,4587 oleh nilai pasar ekuitas. Sedangkan Bank BNI dan Bank Mandiri memiliki nilai rasio $\mathrm{X}_{4}$ masing-masing sebesar 0,2546 atau $25,46 \%$ dan 0,3389 atau $33,89 \%$.

Analisis statistik deskriptif dipergunakan untuk mengetahui nilai rata-rata, minimum, dan maksimum variabel. Berikut ini merupakan hasil statistik deskriptif untuk rasio $\mathrm{X}_{1}, \mathrm{X}_{2}, \mathrm{X}_{3}$, dan $\mathrm{X}_{4}$ dari keempat Bank BUMN periode 2019 :

Tabel. 1 Hasil Analisis Statistik Deskriptif pada Bank BUMN periode 2019

\begin{tabular}{|c|c|c|c|c|}
\hline Variabel & $\mathbf{N}$ & Min & Max & Mean \\
\hline $\mathrm{X}_{1}$ & 4 & 0,1157 & 0,2092 & 0,1599 \\
\hline $\mathrm{X}_{2}$ & 4 & 0,0006 & 0,0139 & 0,0092 \\
\hline $\mathrm{X}_{3}$ & 4 & 0,0013 & 0,0804 & 0,0253 \\
\hline $\mathrm{X}_{4}$ & 4 & 0,0833 & 0,4587 & 0,2968 \\
\hline
\end{tabular}

1. Working Capital to Total Assets $\left(\mathrm{X}_{1}\right)$

Dari Tabel 1, dapat dilihat nilai variabel $\mathrm{X}_{1}$ terendah yaitu sebesar 0,1157 yang dimiliki oleh Bank BNI. Sedangkan untuk nilai variabel $\mathrm{X}_{1}$ tertinggi yaitu sebesar 0,2092 yang dimiliki oleh Bank BTN. Nilai rata-rata pada variabel $\mathrm{X}_{1}$ adalah sebesar 0,1599.

2. Retained Earning to Total Assets $\left(\mathrm{X}_{2}\right)$

Nilai rasia $\mathrm{X}_{2}$ terendah yaitu sebesar 0,0006 yang dimiliki oleh Bank BTN. Sedangkan untuk 
nilai variabel $\mathrm{X}_{2}$ tertinggi yaitu sebesar 0,0139 yang dimiliki oleh Bank BNI. Nilai rata-rata pada variabel $\mathrm{X}_{2}$ adalah sebesar 0,0092 .

\section{Earning Before Interest And Taxes to Total Assets $\left(\mathrm{X}_{3}\right)$}

Nilai variabel $\mathrm{X}_{3}$ terendah yaitu sebesar 0,0013 yang dimiliki oleh Bank BTN. Sedangkan untuk nilai variabel $\mathrm{X}_{3}$ tertinggi yaitu sebesar 0,0804 yang dimiliki oleh Bank BRI. Nilai ratarata pada variabel $\mathrm{X}_{3}$ adalah sebesar 0,0253 .

\section{Market Value of Equity to Book V alue of Total Debt $\left(\mathrm{X}_{4}\right)$}

Nilai rasio $\mathrm{X}_{4}$ terendah yaitu sebesar 0,0833 yang dimiliki oleh Bank BTN. Sedangkan untuk nilai variabel $\mathrm{X}_{4}$ tertinggi yaitu sebesar 0,4587 yang dimiliki oleh Bank BRI. Nilai rata-rata pada variabel $\mathrm{X}_{4}$ adalah sebesar 0,2968 .

Setelah melakukan perhitungan terhadap masing-masing rasio pada Bank BUMN, langkah selanjutnya adalah menghitung nilai Z-Score untuk tiap-tiap Bank BUMN dengan memasukkan hasil perhitungan rasio tersebut ke dalam model persamaan $Z-S c o r e$ modifikasi dengan mengalikan hasil rasio dengan nilai koefisien dari masing-masing variabel. Rumus $Z$-Score yang digunakan adalah

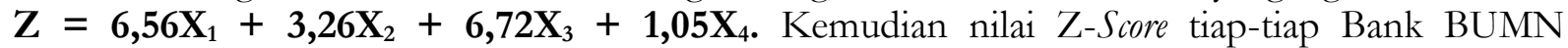
diklasifikasikan sesuai nilai cut-off model Altman Z-Score. Berikut ini hasil perhitungan dengan metode Z-Score modifikasi pada Bank BUMN periode 2019 :

Tabel. 2 Hasil Perhitungan dengan Metode Z-Score Modifikasi pada Bank BUMN periode 2019

\begin{tabular}{|c|c|c|c|c|c|c|}
\hline No & Nama Bank & $6,56 \mathrm{X}_{1}$ & $3,36 \mathrm{X}_{2}$ & $6,72 \mathrm{X}_{3}$ & $1,05 \mathrm{X}_{4}$ & Z-Score \\
\hline 1 & Bank BRI & 0,1994 & 0,0097 & 0,0804 & 0,4587 & 2,362 \\
\hline 2 & Bank BNI & 0,1157 & 0,0139 & 0,0229 & 0,2546 & 1,226 \\
\hline 3 & Bank Mandiri & 0,1204 & 0,0086 & 0,0276 & 0,3389 & 1,360 \\
\hline 4 & Bank BTN & 0,2092 & 0,0006 & 0,0013 & 0,0833 & 1,471 \\
\hline
\end{tabular}

Berdasarkan Tabel 2 dari hasil perhitungan menggunakan metode Z-Score Modifikasi pada masing-masing Bank BUMN pada periode 2019, menunjukkan bahwa nilai Z-Score keseluruhan pada Bank BUMN periode 2019 berada diantara 1,10 dan 2,90 (1,10<Z-Score < 2,90). Artinya seluruh Bank BUMN berada pada kategori grey area atau rawan bangkrut. Untuk periode 2019 nilai $Z$-Score tertinggi dimiliki oleh bank BRI sebesar 2,362. Bank BTN menempati posisi kedua nilai ZScore tertinggi yaitu sebesar 1,471 diikuti oleh Bank Mandiri dengan nilai Z-Score sebesar 1,360. Sedangkan nilai Z-Score terendah ditempati oleh Bank BNI dengan nilai Z-Score sebesar 1,226.

Setelah melakukan perhitungan nilai rasio- rasio keuangan dalm Z-Score, kemudian menghitung nilai Z-Score untuk masing-masing Bank BUMN, dan melakukan analisis nilai Z-Score. Selanjutnya, dilakukan pembahasan pada Bank BUMN selama periode 2019 
Tabel. 3 Hasil Penilaian Z-Score pada Bank BUMN periode 2019

\begin{tabular}{|c|l|c|c|}
\hline No & Nama Bank & Z-Score & Hasil Analisis \\
\hline 1 & Bank BRI & 2,362 & Rawan bangkrut \\
\hline 2 & Bank BNI & 1,226 & Rawan bangkrut \\
\hline 3 & Bank Mandiri & 1,360 & Rawan bangkrut \\
\hline 4 & Bank BTN & 1,471 & Rawan bangkrut \\
\hline
\end{tabular}

Berdasarkan Tabel IV.7 dapat dilihat bahwa kondisi keempat Bank BUMN berada pada grey zone atau rawan bangkrut atau kondisi keuangan tidak dapat ditentukan. Daerah rawan bangkrut menunjukkan bahwa pertumbuhan yang dialami Bank BUMN dapat meningkat atau menurun, apabila manajemen perusahaan tidak melakukan rencana keuangan yang matang, kemungkinan besar akan terancam mengalami kebangkrutan dalam jangka waktu satu sampai dua tahun mendatang. Hasil keseluruhan yang mengindikasikan keempat Bank BUMN berada pada zona rawan bangkrut karena hasil perhitungan rasio Retained Earnings to Total Assets $\left(\mathrm{X}_{2}\right)$ dan Earning Before Interest and Taxes to Total Assets $\left(\mathrm{X}_{3}\right)$ yang sangat rendah.

Menilik dari laporan tahunan dan laporan keuangan keempat Bank BUMN rendahnya nilai rasio $\mathrm{X}_{2}$ dan $\mathrm{X}_{3}$ adalah karena besarnya nilai nomilan asset yang dimiliki oleh masing-masing Bank BUMn tidak diimbangi dengan nilai laba yang ditahan dan EBIT yang diperoleh, atau dapat dikatakan bahwa nilai laba yang ditahan dan EBIT tidak dapat mengimbangi total asset yang sangat besar sehingga mempengaruhi nilai rasio $\mathrm{X}_{2}$ dan $\mathrm{X}_{3}$ menjadi rendah.

Hasil perhitungan nilai rasio tentunya sangat berpengaruh terhadap hasil akhir nilai Z-Score yang didapat. Apabila rasio yang diperoleh rendah makan akan menghasilkan nilai Z-Score rendah dan sebaliknya, apabila nilai rasio yang diperoleh tinggi maka hasil perhitungan Z-Score juga akan tinggi.

Bank BRI walaupun pada posisi yang sama dengan bank-bank lainnya tetapi memiliki Z-score yang tertinggi yaitu sebesar 2,362. Adapun alasan kenapa Bank BRI memiliki nilai Z-Score yang tinggi karena dipengaruhi nilai rasio $\mathrm{X}_{3}$ dan $\mathrm{X}_{4}$ yang tinggi dibandingkan dengan bank lain. Besarnya nilai rasio $\mathrm{X}_{3}$ pada Bank BRI dikarenakan nilai nominal EBIT yang diperoleh Bank BRI selama periode 2019 yang tinggi yaitu sebesar Rp.113.929.768 juta dibandingkan dengan bank BUMN yang lain. Selain itu juga, pada rasio $\mathrm{X}_{4}$ Bank BRI memperoleh nilai yang tinggi dikarenakan nominal market value Bank BRI tinggi yaitu sebesar Rp. 542.721.564 juta, tertinggi dibandingkan ketiga bank lainnya.

\section{Penutup}

Berdasarkan hasil analisis data dan pembahasan yang telah dilakukan untuk mengetahui potensi kebangkrutan pada Bank BUMN menurut metode Alman Z-Score pada periode 2019 menunjukkan bahwa: Hasil perhitungan Z-Score menunjukkan nilai Z-Score yang diperoleh Bank BUMN berada diantara 1,10 dan 2,90 (1,10<Z-Score < 2,90). Dan berdasarkan kriteria penilaian Z-Score, keempat Bank BUMN dapat dikaregorikan kedalam kondisi keuangan yang tidak dapat ditentukan atau berada dalam grey zone. 
Berdasarkan hasil penelitian yang diperoleh, maka dapat dikemukakan beberapa saran yang diharapkan bermanfaat bagi pihak-pihak yang berkepentingan. Bagi pihak manajemen perusahaan, hasil penelitian menunjukkan bahwa keempat Bank BUMN memiliki nilai rasio $\mathrm{X}_{2}$ (Retained Earnings to Total Assets) dan $\mathrm{X}_{3}$ (Earning Before Interest and Taxes to Total Assets) yang rendah, manajemen Bank BUMN harus meningkatkan nilai rasio $\mathrm{X}_{2}$ dan $\mathrm{X}_{3}$ dengan cara meningkatkan nilai nominal Retained Earning, dan juga nilai nominal EBIT yang dimiliki oleh masing-masing Bank BUMN. Dan bagi peneliti selanjutnya, diharapkan menggunakan jangka waktu penelitian lebih dari satu tahun agar dapat memperoleh hasil yang lebih objektif. Selain itu agar peneliti selanjutnya dapat menambah alat analisis sehingga dapat dijadikan perbandingan dan hasil penelitian lebih optimal.

\section{Daftar Pustaka}

Altman, E. I. (1968). Financial Ratios, Discriminant Analysis Bankcruptcy · Journal Of Financial.

Anggrain, Y. R. (2011 ). Analisis Prediksi Kebangkrutan Perbankan Berdasarkan Model Altman's Z-Score Pada Pt. Bank Rakyat Indonesia (Persero), Tbk. . Universitas Jember.

Endri. (2018). Prediksi Kebangkrutan Bank Untuk Menghadapi Dan Mengelola Perubahan Lingkungan Bisnis: Analisis Model Altman's Z-Score. Universitas Mercu.

Fahmi, I. (2011). Analisis Laporan Kenangan. Lampulo: Alfabeta.

Firda Mastuti, M. S. (2012). Altman Z-Score Sebagai Salah Satu Metode Dalam Menganilisis Estimasi Kebangkrutan Perusahaan (Studi pada perusahaan Plastik dan Kemasan yang Terdaftar (listing) di Bursa Efek Indonesia periode Tahun 2010 sampai dengan 2012. Universitas Brawijaya.

Ginanjar, L. (2017 ). Prediksi Kebangkrutan Sebelum Dan Sesudah Merger Pada Pt Bakrie Telcom Tbk Menggunakan Model Altman Z-Score Modifikasi, 1995 . Politeknik Negeri Bandung.

Haliman, N. (2015). Prediksi Kebangkrutan Pada Pt. Bakrie \& Brothers Tbk Dengan Menggunakan Altman Z-Score Periode 2011-2015 . Politeknik Negeri Bandung.

I Komang Try Satriawan Korry, M. P. (2019). Analisis Prediksi Kebangkrutan Berdasarkan Metode Altman Z-Score (Studi Kasus Pada Bank Bumn Yang Terdaftar Di Bei). Universitas Warmadewa.

Kasmir. (2004). Bank Dan Lembaga Keuangan Lainnya . Jakarta : Pt. Raja. Grafindo Persada.

Maria Florida Sagho, N. K. (2015). Penggunaan Metode Altman Z-Score Modifikasi Untuk Memprediksi Kebangkrutan Bank Yang Terdaftar Di Bursa Efek Indonesia . Universitas Udayana.

Mauddina, G. (2017). Analisis Prediksi Kebangkrutan Pt. Bank Muamalat Indonesia. Tbk Periode 2013-2017. Politeknik Negeri Bandung.

Meisya, V. (2015). Penilaian Kinerja Keuangan Dan Prediksi Kebangkrutan Pada Pt Ultrajaya Milk Tbk Periode 2012-2015. Politeknik Negeri Bandung.

Nainggolan, H. (2017). Analisis Resiko Keuangan Dengan Model Altman Z- Score Pada Perusahaan Perbankan Di Indonesia (Listed Di Bursa Efek Indonesia). Sekolah Tinggi Ilmu Ekonomi Balikpapan.

Permanasari, R. ( 2006 ). Analisis Kebangkrutan Dengan Menggunakan Model Altman (Z-Score) Dan Zavgren (Model Logit) Pada Perusahaan Food And Beverage. Universitas Brawijaya.

Prihado, T. (2010 ). Analisis Laporan Kenangan Teori Dan Aplikasi . Jakarta : Ppm.

S.Munawir. (2002). Analisis Laporan Kenangan, Edisi Keempat. Yogyakarta : Liberty. 
Nita Kurniasih, Muhammad Umar Mai, Rani Putri Kusuma Dewi

Sartono, A. (1996). Manajemen Keuangan: Teori Dan Aplikasi Edisi Tiga . Yogyakarta : Bpfe.

Sunarto. (2006). Bisnis . Yogyakarta: Amus.

Tristantyo, Y. R. (2012 ). Analisis altman Z-Score Dalam Memprediksi Kebangkrutan Pada Perusahaan Perbankan Swasta Nasional Devisa Yang Go Public Di BEI . Universitas Widyatama. 